\section{Yield and Nutrient Content of Bell Pepper Pods from Plants Developed from Seedlings Inoculated, or Not, with Microorganisms}

\author{
Vincent M. Russo ${ }^{2}$ and P. Perkins-Veazie ${ }^{1}$ \\ USDA/ARS, South Central Agricultural Research Laboratory, 911 Highway \\ 3W, Lane, OK 74555
}

Additional index words. arbuscular mycorrhizae, bacteria, carotenoid, chlorophyll, conventional, fungus, organic, vitamin $\mathrm{C}$

\begin{abstract}
The effectiveness of microorganisms applied in production of vegetable transplants has had mixed results. Bell pepper (Capsicum annuum L.) transplants were grown in a greenhouse using organic methods and the organic-certified potting mix was inoculated, or not, with beneficial bacteria or arbuscular mycorrhizal (AM) fungi, or both. Other transplants were grown in the same greenhouse with a conventional potting mix, which was not inoculated. Transplants were established in the field at various planting dates in a Bernow or Stigler soil and grown using conventional or organic methods. Pod yield and nutrient contents were determined. Yields of organically grown plants were similar to those of conventionally grown plants when both were grown on the Bernow soil. When grown on both soil types, yield was higher for the Bernow than for the Stigler soil. Treatment had little effect on pod mineral content. Chlorophylls, total carotenoid, and vitamin $C$ contents of pods from plants grown on the Stigler soil were generally lower than those from plants grown on the Bernow soil. Average pod fresh weight for plants developed from seedlings inoculated with beneficial bacteria or AM fungi was greater than that from plants developed from conventionally grown seedlings. Inoculation did not improve fresh pod weights over that from plants developed from organically grown, but not inoculated, seedlings. Amending potting mix with the microorganisms tested did not provide extraordinary benefit or detriment for use in production of bell pepper.
\end{abstract}

Field establishment of vegetables using transplants is a common practice in the United States. Research on transplant production has focused on ways to produce seedlings that meet mechanization requirements, survive field establishment, contribute to plant health, and improve yield of plants developed from the transplants (Cantliffe, 1993; Damato and Trotta, 2000; de Grazia et al., 2002; Dufault, 1998; Hartz et al., 2002; Maynard, 2000; Nicola et al., 2004; Russo,

Received for publication 16 Dec. 2009. Accepted for publication 4 Jan. 2010.

Mention of a trademark, vendor, or proprietary product does not constitute a guarantee or warranty of the product by the U.S. Department of Agriculture (USDA) and does not imply its approval to the exclusion of other products that may be suitable. USDA employees prepared the article as part of their official duties. Copyright protection under U.S. copyright law is not available for such works, and there is no copyright to transfer. The fact that the private publication in which the article appears is itself copyrighted does not affect the material that is a work product of the U.S. government, which can be freely reproduced by the public.

${ }^{1}$ Current address: Plants for Human Health Institute, NC Research Campus, 600 Laureate Way, Suite 1329, Kannapolis, NC 28081.

${ }^{2}$ To whom reprint requests should be addressed; e-mail vincent.russo@ars.usda.gov.
2004; Sterrett et al., 1983; Vavrina, 1998). Plant- and animal-based fertilizers have been used as amendments in vegetable transplant production (Koller et al., 2004).

Mycorrhizal fungi and rhizosphere bacteria are, depending on formulation, permissible for use as amendments in potting media in organic production. Arbuscular mycorrhizae (AM) are fungi that colonize roots of almost all vascular plants (Singh and Adholeya, 2002). Linderman and Davis (2001) added an AM fungus, Glomus intraradices Schenck \& Smith, to soil in containers sown with onion (Allium cepa L.) seed. Plants harvested after 10 weeks were more vigorous as a result of the AM fungus. Glomus sp. have been reported to improve (Douds and Reider, 2003), or not affect, bell pepper (Capsicum annuum L.) yield (Makus, 2005). Amounts of fertilizer and water can affect how plants interact with mycorrhiza (Martin and Stutz, 2004; Waterer and Coltman, 1989). Additional information is required to determine the efficacy of AM fungi in vegetable production.

Rhizosphere bacteria can be beneficial to plant development (Glick, 2004; Lucy et al., 2004; Schulze and Pöschel, 2004; Zehnder et al., 2001). Nodule-forming bacteria (Rhizobium sp., now Sinorhizobium sp.) allow for absorption of nitrogen in legumes, and nitrogen-fixing bacteria can be associated with roots of nonleguminous crops
(Emitiazi et al., 2003; Shimshick and Herbert, 1979; Zahir et al., 2004). Bacteria can interact synergistically with mycorrhizal fungi to increase root colonization by nodulation of roots and amount of nutrients available to plants (Suresh and Bagyaraj, 2002). Rhizosphere bacteria reduced severity of disease at later stages of development of cucurbits (Kokalis-Burelle et al., 2003). When Bacillus subtillis, another plant growth-promoting bacterium, was added to transplant mixes, seedling vigor of pepper, tomato (Solanum lycopersicum L.), strawberry (Fragaria chiloensis var. ananassa Duchesne), and several cucurbits (KokalisBurelle et al., 1999; Rippy et al., 2004) were improved. In long-term greenhouse experiments, addition of bacteria that induce systemic acquired resistance had little effect on tomato (Vavrina and Roberts, 2004). Also, with graminaceous crops, the need for nitrogen fertilizer was not reduced when freeliving and endophytic $\mathrm{N}_{2}$-fixing bacteria were present (Andrews et al., 2003). How Sinorhizobium bacteria may affect development of nonleguminous vegetable transplants is not well known. It is not clear if plant growth-promoting bacteria, especially those normally considered to be symbiotic on legumes, will benefit development of vegetable transplants.

Expanding interest in organic production of vegetables has necessitated development of production systems that meet requirements of the National Organic Program [United States Department of Agriculture, Agricultural Marketing Service (USDA, AMS), 2000]. However, addition of mycorrhizae may not benefit bell pepper production (Makus, 2005). Seedlings designated for transplanting must be grown in only a few weeks with a small volume of potting medium and are entirely dependent on any amendments supplied.

Russo (2005) developed a system in which pepper transplants were grown using a completely organic system, and seedlings were comparable to those produced using conventional methods. Addition of bacteria to planting trays had limited benefits to bell pepper seedling development (Russo, 2006), but long-term effects of inoculation on plant development in the field were not followed. The methods used in transplant production may affect yield and development of plants. It is unclear if these activities will affect deposition of nutrients in edible portions of plants. This project was undertaken to determine if inoculation of potting medium with beneficial microorganisms in which bell pepper transplants will develop, soil type, and conventional or organic field production affects yield and/or nutrient content of pods from plants developed from inoculated seedlings.

\section{Materials and Methods}

Components common to production of all seedlings. Seedlings were produced in a greenhouse at Lane, OK, from late-February to midApril for spring planting dates in 2006, 2007, and 2008 and from early- or mid-June to 
mid-July or early-August for late summer planting dates in 2007 and 2008. Greenhouse temperatures averaged 33/22 $\pm 1{ }^{\circ} \mathrm{C}$ (day/ night). Because outside daytime temperatures in late winter and early spring in southeastern Oklahoma can reach from 20 to $30{ }^{\circ} \mathrm{C}$ within the greenhouse, daytime cooling was provided. Additional light in the morning with fluorescent bulbs (430 lumens $/ \mathrm{m}^{3}$; Sun Agro; Phillips, Somerset, NJ) was used to provide plants with a minimum of $12 \mathrm{~h}$ of a mix of sunlight and artificial light with artificial light being discontinued after $12 \mathrm{~h}$ of daylight occurred. New Speedling ${ }^{\circledR}$ planting trays (American Plant Products, Oklahoma City, OK), $72.5 \times 34.5 \times 6.2 \mathrm{~cm}$ [length $(\mathrm{L}) \times$ width $(\mathrm{W}) \times$ depth $(\mathrm{D})], 128$ cells per tray, were used. Cell dimensions are $3.7 \times 3.7 \mathrm{~cm}(\mathrm{~L} \times$ W) with each cell having a volume of $36 \mathrm{~cm}^{3}$. Trays were placed on benches made of perforated metal $1 \mathrm{~m}$ above the greenhouse floor. New plastic inserts (American Plant Products; $3.5 \times 3.5 \times 6 \mathrm{~cm}, \mathrm{~L} \times \mathrm{W} \times \mathrm{D}$, with cell volumes of $30 \mathrm{~cm}^{3}$ ) were fit within cells of planting trays. Trays were irrigated daily for $2 \mathrm{~min} /$ application at $0900 \mathrm{HR}, 1500 \mathrm{HR}$, and 1800 HR. The misting system on each bench was comprised of three emitters, each of which delivered $\approx 850 \mathrm{~mL} \cdot \mathrm{min}^{-1}\left(5.1 \mathrm{~L} \cdot \mathrm{d}^{-1}\right)$ in a fine mist. Each cell received $\approx 10 \mathrm{~mL}$ of water per day. Over $24 \mathrm{~h}$, from after the 0900 $\mathrm{HR}$ irrigation to before the $0900 \mathrm{HR}$ irrigation the next day, flowthrough was less than $2 \mathrm{~mL}$ per cell.

Organically produced transplants. Seedlings were produced using the methods of Russo (2006), which briefly are: cell inserts were filled halfway with Sunshine LC1 potting medium [SunGro, Bellevue, WA; Organic Materials Review Institute (OMRI), Eugene, OR, listed] with a water-holding capacity of $\approx 320 \mathrm{~mL}$ of water $/ 1000 \mathrm{~cm}^{3}$ of media volume. Major components of the medium are sphagnum, perlite, peatmoss, gypsum, and dolomitic limestone. The medium was moistened with potable quality tap water. The irrigation water and potting medium contributed to nutrients available to plants (Tables 1 and 2).

A mix of bacteria, Sinorhizobium meliloti and S. leguminosarum biovar trifolii (both previously Rhizobium), designated for use with alfalfa and sweet, red, white, alsike, and ladino clovers (Nitragin $\AA$, Milwaukee, WI; 200,000,000 propagules/g), was added to the medium at $0.5 \mathrm{~g} /$ cell of the mix with a scoop having a repository hole with a diameter of $6.2 \mathrm{~mm}$ and a depth of $4.5 \mathrm{~mm}$ to half of the cells in trays. To cells in other trays, a mix of arbuscular mycorrhizal fungi, G. aggregatum Schenck \& Smith emend. Koske, G. intraradices, and G. mosseae (Nicol. \& Gerd.) Gerd \& Trappe (MycoVAM®; Helena Chemical Co., Collierville,
TN; OMRI listed, 123,000 propagules $/ \mathrm{kg}$ ) was added to the medium. To each cell, 0.6 $\mathrm{g} /$ cell of the mix was added with a standardized scoop having a repository hole with a diameter of $11.5 \mathrm{~mm}$ and a depth of 10.5 $\mathrm{mm}$. In other trays, the same amounts of both inocula were added, and in trays acting as organic controls, neither was added. Additional medium was added to the three-fourths point in the cells and moistened. Seed of bell pepper, cv. Jupiter, were sown on the surface of the medium and covered with additional medium to tops of cells. The medium was again moistened.

Three weeks after sowing, at which point emergence was more than $90 \%$, plants were thinned to one/cell. Fertilization with Neptune's Harvest ${ }^{\circledR}$ (Ocean Crest Seafoods, Gloucester, ME; OMRI listed) derived from hydrolyzed fish and seaweed was begun when first true leaves emerged. Before fertilizations, the container with the Neptune's Harvest was shaken to ensure contents were well mixed. The label on the undiluted material indicates it provides $2 \mathrm{~N}-3 \mathrm{P}-1 \mathrm{~K}$. The fertilizer was mixed at $30 \mathrm{~mL} \cdot \mathrm{L}^{-1}$, four times the label recommendation (Russo, 2005), and $500 \mathrm{~mL}$ was applied to each tray (Table 2). For all plants, fertilization was applied weekly for 5 weeks. Unused material was kept in the closed container.

Conventionally produced transplants. Other trays were filled with the conventional potting medium Reddi-Earth ${ }^{\circledR}$ (Scotts-Sierra Horticultural Products, Marysville, $\mathrm{OH}$ ) and seed of the same cultivar sown in the same manner as previously stated. For purposes of this project, conventional transplant production is understood to mean that a medium containing synthetic materials was used, the medium was amended with synthetic fertilizer, and no biological amendments were added. The irrigation water and the potting medium contributed to nutrients available to plants (Tables 1 and 2).

Fertilization with Peters 20-20-20 soluble fertilizer (Spectrum Group, St. Louis, MO) was begun at the same time as for organically produced transplants. The fertilizer was mixed at $5 \mathrm{~g} \cdot \mathrm{L}^{-1}$ and $500 \mathrm{~mL}$ applied to trays. The fertilization level was previously used to produce transplants comparable to those treated with organic methods and materials (Russo, 2005). For all plants, fertilization was applied weekly for 5 weeks.

Field preparation. Experiments were conducted on a Bernow fine-loamy, siliceous, thermic Glossic Paleudalf or a Stigler fine, mixed, thermic Aquic, Paleudalf, soil (Shingleton and Watterson, 1979). There was $\approx 100 \mathrm{~m}$ between fields with the Bernow and Stigler soils. The Stigler soil is heavier, holds water longer, and at Lane, OK, situated at a slightly lower elevation. Wheat (Triticum vulgaris L.) had been sown as a cover crop in the preceding early fall of each year.

For organic production, the winter cover was disked under in late January of each year and $5 \mathrm{t} \cdot \mathrm{ha}^{-1}$ of chicken litter, aged more than 5 months, was applied and disked under. When there was a second planting in the year on the same beds, there was no additional manure applied to the soil.

For conventional production, the winter cover was disked under $\approx 2$ weeks before transplanting. A conventional fertilizer mix (13N-13P-13K) was applied within 1 week before planting to bring recommended (Motes and Roberts, 1994) levels to $56 \mathrm{~N}-80 \mathrm{P}-280 \mathrm{~K}$ $\mathrm{kg} \cdot \mathrm{ha}^{-1}$. The nitrogen was from urea, phosphorus was from $\mathrm{P}_{2} \mathrm{O}_{5}$, and potassium from muriate of potash. The soil was treated with trifluorlin incorporated with a rolling cultivator.

Seedlings were established on conventionally (Bernow) and organically (Stigler) managed soils. The Bernow soil had supported vegetable crops for several years. The Stigler soil had been in bell pepper production using organic methods for 2 years after conversion from perennial pasture. Experiments were begun in 2006 and repeated in 2007 and 2008. Additional Bernow soil plot area, previously supporting crops grown with organic methods (Russo and Taylor, 2006), became available in 2008 and was used for production of plants using organic methods.

Soil preparation and maintenance common to all plants. The soil was shaped into beds on $0.9-\mathrm{m}$ centers. Plants were established with a mechanical transplanter with $45-\mathrm{cm}$ in-row spacing (20 plants/row) into bare soils on 19 Apr. 2006, 20 Apr. and 15 July 2007, and 16 Apr. and 1 Aug. 2008. Plots were $9 \mathrm{~m}$ long. All treatments were replicated three times. To prevent crossinoculation of treatments, there were unplanted rows between treatment rows and $2 \mathrm{~m}$ unplanted areas between treatments. For each planting date, seedlings with the same treatments were established in the same rows in plots. Supplemental water was provided with overhead irrigation when precipitation was less than $2.5 \mathrm{~cm}$ per week. It was not necessary to control insects or diseases in any year. Weed control in all plots after plant establishment was with mechanical or hand cultivation. Harvest occurred when pods were at a minimum US\#1 grade (USDA, AMS, 1999).

Data collection and statistical analysis. The soil types were substantially different, and after transplanting, conventional production practices were not used where organic production occurred. Measurements from plants under conventional (Bernow) and organic (Stigler) production were analyzed separately in 2006 and 2007. Treatments

Table 1. Values for constituents ${ }^{\mathrm{z}}$ of the irrigation water used in the greenhouse

\begin{tabular}{|c|c|c|c|c|c|c|c|c|c|c|c|}
\hline $\mathrm{pH}$ & $\mathrm{NO}_{3}-\mathrm{N}$ & Potassium & Boron & Calcium & Chlorine & $\begin{array}{l}\text { Sodium } \\
-1) \text { - }\end{array}$ & $\mathrm{CaCO}_{3}$ & Magnesium & $\mathrm{SO}_{4}$ & Hardness & $\begin{array}{c}\text { Electrical conductivity } \\
\left(\mu \mathrm{mhos} \cdot \mathrm{cm}^{-1}\right)\end{array}$ \\
\hline 9.5 & $<1$ & 2 & 0.07 & 13 & 15 & 16 & 41 & 2 & 12 & 39 & 151 \\
\hline
\end{tabular}

${ }^{z}$ Analyses performed by the Oklahoma State University Soil, Water \& Forage Analytical Laboratory, Stillwater, OK. 


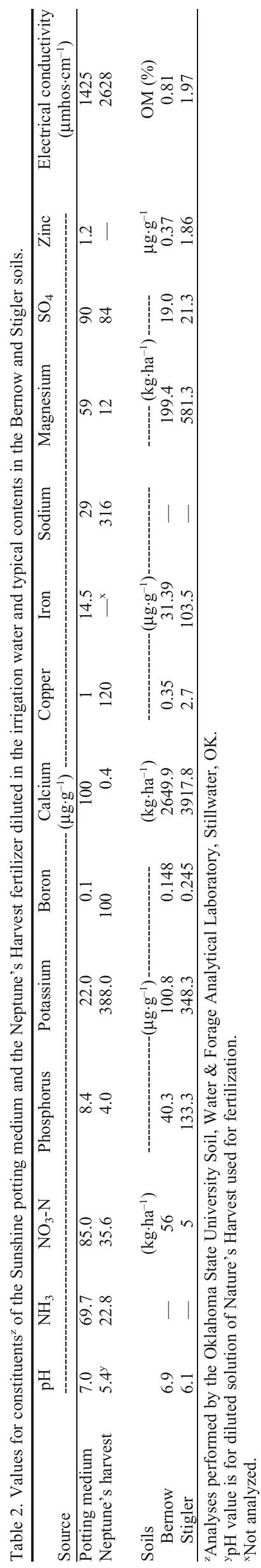

were planting date and pretransplanting inoculation treatment. Marketable and cull yields were obtained in all years. There were generally no more than three weekly harvests in a growing season.

Year 2008 provided specific opportunities. In addition to affects of pretransplanting inoculation, yields from plants grown on the Bernow or Stigler soils grown with organic methods were directly compared, and plants grown with conventional and organic methods on the Bernow soil were directly compared.

In 2008, nutrient content of pods taken from plants at the first harvest was determined by flow injection analysis, or ion chromatography, using a Lachat 8000 analytical system (Hach Co., Loveland, CO). For determination of total nitrogen (TKN) and phosphorus (TKP) in a Kjeldahl digest, tissues were processed according to the procedures of Jones and Case (1990). Analysis was with methods provided by the manufacturer (TKN: QuikChem method 13-107-06-2-D; TKP: QuikChem method 13115-01-1-B). To determine levels of ions, tissues were extracted according to the methods of Russo and Karmakar (1998). Levels of calcium, potassium, magnesium, sodium, nitrate-N, nitrite-N, phosphate $\left(\mathrm{PO}_{4}\right)$, and sulfate $\left(\mathrm{SO}_{4}\right)$ were determined following methods provided by the manufacturer (anions: QuikChem method 10-510-00-1-A; cations: QuikChem method 10-520-00-1-B). Levels of chlorophyll, carotenoids, and vitamin $\mathrm{C}$ in pods were determined. Chlorophyll and carotenoids were extracted from tissues and quantified with an ultraviolet-VIS spectrophotometer (ultraviolet-2450; Shimadzu, Kyoto, Japan) using the methods of Lichtenhaler and Buschmann (2001). Chlorophyll $a$ was measured at the 664-nm wavelength, chlorophyll $b$ at the 647$\mathrm{nm}$ wavelength, and carotenoids at the 470-nm wavelength. Total vitamin $\mathrm{C}$ was determined with the methods of Hodges et al. (2001) with readings at the 525-nm wavelength. Whole pod fresh weights were determined so that chlorophyll, carotenoid, and vitamin $\mathrm{C}$ levels could be extrapolated to amounts present in intact marketable pods. All measurements were compared with appropriate standards.

At each planting, the experimental design was a randomized complete block. Data were subjected to analysis of variance in SAS (SAS Inc., Cary, NC) to determine significance of main and interaction effects. When present, the interaction was given preference in explaining results. If interactions were not present, the Ryan-Einot-Gabrielle-Welsch multiple F test in SAS was used to separate main effects means.

\section{Results}

Typical soil tests indicated that the Stigler soil had lower $\mathrm{NO}_{3}-\mathrm{N}$ and higher phosphorus, potassium, boron, calcium, copper, iron, sodium, magnesium, $\mathrm{SO}_{4}$, zinc, and organic matter than the Bernow soil (Table 2). Rain amounts in 2007 affected plantings established in the Stigler soil and there were no harvests from those plots for either planting date in 2007.
Yield in all years. Response to planting date, inoculation treatment, and their interaction were different for the production practices (Table 3). Planting date, but not inoculation treatment or the interaction, affected marketable and cull yields in conventional production on the Bernow soil, whereas organic production on the Bernow soil had no affect as a result of treatment. Planting date, but not inoculation treatment, affected marketable and cull yields and the interaction affected marketable yields in organic production on the Stigler soil.

For conventionally grown plants on the Bernow soil, marketable and cull yields were highest for those established in Spring 2006 (Table 4). In the next years, marketable yield was lower for plants established in the spring than in the summer of each year. In 2007 and 2008, cull yield for plants established in the spring were higher, or equal to those, for plants established in the summer. For plants grown organically on the Stigler soil, marketable yields were similar for plants established in Spring 2006 and Summer 2008 and higher than for those from plants established in Spring 2008. Cull yields for these plants were highest for the Spring 2006 planting and lower and similar for plants established in Spring and Summer 2008

For plants grown on the Stigler soil, the planting date by inoculation treatment interaction did not affect marketable yield for plants established in the springs of 2006 and 2008 but did affect marketable yield for plants established in the Summer 2008 (Table $5)$. For the latter plants, those developed from conventionally grown transplants and those developed from organically grown seedlings receiving no inocula or those inoculated with both organisms had similar yields. Marketable yield for plants developed from organically grown transplants inoculated with the bacteria or the AM fungi were similar and lower.

Yield and comparison of organically grown plants on Bernow and Stigler soils, 2008. When transplants were established on the two soil types in 2008 and grown organically, soil type, but not planting date or inoculation treatment, affected marketable and cull yield (Table 6). Plants grown on the Bernow soil had higher marketable and cull yields than those grown on the Stigler soil.

Yield and comparison of plants grown conventionally or organically only on the Bernow soil, 2008. Planting date and the production method $\times$ planting date interaction affected marketable yield; management type only affected cull yield (Table 7). Plants established in the spring had a higher marketable yield with organic production with similar marketable yields between production methods in summer-established plants. Planting date had no effect on cull yield with fewer culls with conventional management, $0.2 \mathrm{t} \cdot \mathrm{ha}^{-1}$, than from those produced organically, $1.3 \mathrm{t} \cdot \mathrm{ha}^{-1}$.

Pod mineral content of organically grown plants on Bernow and Stigler soils, 2008. The 
Table 3. Analysis of variance table for effects of planting date and pretransplanting inoculation on marketable and cull yield of bell pepper from plants grown with conventional or organic methods in Bernow or Stigler soils with organic or conventional methods.

\begin{tabular}{|c|c|c|c|c|c|c|}
\hline \multirow[b]{3}{*}{ Source } & \multicolumn{2}{|c|}{ Conventional production, Bernow soil ${ }^{\mathrm{z}}$} & \multirow{2}{*}{\multicolumn{2}{|c|}{$\begin{array}{c}\text { Organic production, Bernow soil } \\
\text { Total }\end{array}$}} & \multirow{2}{*}{\multicolumn{2}{|c|}{$\frac{\text { Organic production, Stigler soil }}{\text { Total }}$}} \\
\hline & \multicolumn{2}{|c|}{ Total } & & & & \\
\hline & Marketable & Cull & Marketable & Cull & Marketable & Cull \\
\hline Planting date $(\mathrm{P})$ & $* *$ & $* *$ & NS & NS & * & $* *$ \\
\hline Inoculation treatment (I) & NS & NS & NS & NS & NS & NS \\
\hline \multicolumn{7}{|l|}{ Interaction } \\
\hline $\mathrm{P} \times \mathrm{I}$ & NS & NS & NS & NS & * & NS \\
\hline
\end{tabular}

${ }^{\mathrm{z} B e r n o w}$ fine-loamy, siliceous, thermic Glossic Paleudalf; Stigler fine, mixed, thermic Aquic, Paleudalf.

Ns, $* * *=$ Nonsignificant or significant at $P \leq 0.05$ or $P \leq 0.01$, analysis of variance.

Table 4. Effect of planting date on marketable and cull yield from plants developed from seedlings grown conventionally on the Bernow or organically on the Stigler soil.

\begin{tabular}{|c|c|c|c|c|}
\hline \multirow[b]{2}{*}{ Planting date } & \multicolumn{2}{|c|}{$\begin{array}{l}\text { Bernow soil (conventional) } \\
\text { Total yield }\left(\mathrm{Mg}^{2} \cdot \mathrm{ha}^{-1}\right)\end{array}$} & \multicolumn{2}{|c|}{ 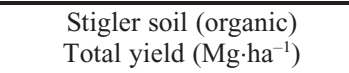 } \\
\hline & Marketable & Cull & Marketable & Cull \\
\hline Spring 2006 & $16.8 \mathrm{a}^{\mathrm{z}}$ & $2.5 \mathrm{a}$ & $7.6 \mathrm{a}$ & $2.0 \mathrm{a}$ \\
\hline Spring 2007 & $11.0 \mathrm{c}$ & $1.1 \mathrm{~b}$ & $-\mathrm{y}$ & - \\
\hline Summer 2007 & $14.1 \mathrm{~b}$ & $0.4 \mathrm{c}$ & - & - \\
\hline Spring 2008 & $3.8 \mathrm{~d}$ & $0.4 \mathrm{c}$ & $4.3 \mathrm{~b}$ & $0.6 \mathrm{~b}$ \\
\hline Summer 2008 & $9.0 \mathrm{c}$ & $0.2 \mathrm{c}$ & $6.9 \mathrm{a}$ & $0.6 \mathrm{~b}$ \\
\hline
\end{tabular}

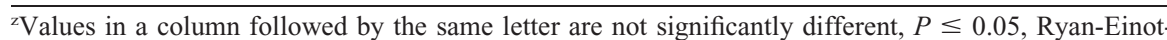
Gabriel-Welsch multiple range test.

y "_-" = No data for these planting dates.

Table 5. Interaction affect of planting date $\times$ inoculation treatment on marketable yield of plants grown organically on a Stigler soil.

\begin{tabular}{llc}
\hline Planting date $\times$ & \multicolumn{1}{c}{ Inoculation treatment } & $\begin{array}{c}\text { Marketable } \\
\text { yield }\left(\mathrm{Mg}^{-1} \mathrm{ha}^{-1}\right)\end{array}$ \\
\hline Spring 2006 & None (conventional) & 6.0 \\
& Organic-no microorganisms & $7.4 \mathrm{NS}$ \\
& Organic-bacteria & $10.1 \mathrm{NS}$ \\
& Organic-AM fungi & $8.3 \mathrm{NS}$ \\
& Organic-both organisms & $6.0 \mathrm{NS}$ \\
Spring 2008 & None (conventional) & 4.0 \\
& Organic-no microorganisms & $4.5 \mathrm{NS}$ \\
& Organic-bacteria & $4.7 \mathrm{NS}$ \\
& Organic-AM fungi & $4.9 \mathrm{NS}$ \\
& Organic-both organisms & $3.4 \mathrm{NS}$ \\
Summer 2008 & & 13.2 \\
& None (conventional) & $8.7 \mathrm{NS}$ \\
& Organic-no microorganisms & $7.8 \mathrm{NS}$ \\
& Organic-both organisms & $2.9 *$ \\
& Organic-bacteria & $2.2 \mathrm{NS}$ \\
\hline
\end{tabular}

Ns, $*=$ Nonsignificant or significant at $P \leq 0.05$ for values in planting date $\times$ inoculation treatment group, least squares means analysis.

$\mathrm{AM}=$ arbuscular mycorrhizal.

Table 6. Analysis of variance table for affects of soil type, planting date, and inoculation treatment, and effect of soil type on marketable and cull yield of organically grown plants on Bernow or Stigler soils (2008).

\begin{tabular}{lcc}
\hline & \multicolumn{2}{c}{ Yield $\left(\mathrm{Mg} \cdot \mathrm{ha}^{-1}\right)$} \\
\cline { 2 - 3 } Source & Marketable & Cull \\
\hline Soil type & NS & $*$ \\
Planting date & $\mathrm{NS}$ & $\mathrm{NS}$ \\
Inoculation treatment & & $\mathrm{NS}$ \\
& & \\
Soil type & $10.5 \mathrm{a}^{\mathrm{z}}$ & $1.3 \mathrm{a}$ \\
$\quad$ Bernow & $5.6 \mathrm{~b}$ & $0.7 \mathrm{~b}$ \\
$\quad$ Stigler & 5.6 &
\end{tabular}

${ }^{\mathrm{z}}$ Values in a column followed by the same letter are not significantly different, $P \leq 0.05$, Ryan-EinotGabriel-Welsch multiple range test.

Ns, ${ }^{*}=$ Nonsignificant or significant at $P \leq 0.05$, analysis of variance, there were no significant interactions. analysis of variance indicated that soil type affected $\mathrm{PO}_{4}, \mathrm{Fl}$, and $\mathrm{SO}_{4}$ contents, but inoculation treatment, or the interaction, did not affect pod nutrient content. Average values of nitrogen in a Kjeldahl digest, nitrate-N, nitrite$\mathrm{N}$, phosphorus in a Kjeldahl digest, potassium, bromide, calcium, chloride, magnesium, and sodium were: $2.1,0.4,0.74,0.32,0.08,24.2$, $1.16,19.5,85.2$, and $0.11 \mu \mathrm{g} \cdot \mathrm{g}^{-1}$, respectively. Pods from plants grown on the Stigler soil had lower $\mathrm{PO}_{4}$ values $\left(2.8 \mu \mathrm{g} \cdot \mathrm{g}^{-1}\right)$ versus 2178.6 $\mu \mathrm{g} \cdot \mathrm{g}^{-1}$ for the Bernow and lower F1 (176.4 $\mu \mathrm{g} \cdot \mathrm{g}^{-1}$ ) versus $255.7 \mu \mathrm{g} \cdot \mathrm{g}^{-1}$ for the Bernow and $\mathrm{SO}_{4}$ values $\left(7503.0 \mu \mathrm{g} \cdot \mathrm{g}^{-1}\right)$ versus $6,123.6$ $\mu \mathrm{g} \cdot \mathrm{g}^{-1}$ for the Bernow.

Pod nutrient content of plants grown conventionally or organically only on the Bernow soil, 2008. The analysis of variance indicated that only pod Fl level was affected in plants grown on the Bernow soil with conventional or organic methods. Average values of nitrogen in a Kjeldahl digest, nitrate-N, nitrite-N, phosphorus in a Kjeldahl digest, $\mathrm{PO}_{4}$, potassium, bromide, calcium, chloride, magnesium, sodium, and $\mathrm{SO}_{4}$ were: $1.7,0.8,1.39,0.24,48.9,0.004,0.002,2.35$, $26.45,1.50,0.004$, and $126.1 \mu \mathrm{g} \cdot \mathrm{g}^{-1}$, respectively. Pods from plants grown organically had higher Fl levels $\left(5.11 \mu \mathrm{g} \cdot \mathrm{g}^{-1}\right)$ than did pods from plants grown conventionally $\left(0.009 \mu \mathrm{g} \cdot \mathrm{g}^{-1}\right)$.

Pod chlorophyll, carotenoid, vitamin $C$ contents, and pod fresh weights of organically grown plants on Bernow and Stigler soils, 2008. Soil type affected chlorophyll $b$, total vitamin $\mathrm{C}$ content, and pod fresh weights; inoculation treatment affected carotenoid content and pod fresh weight and the soil type $x$ inoculation treatment interaction affected all measured variables (Table 8).

Chlorophyll. For plants developed from conventionally and uninoculated, organically produced seedlings, levels of chlorophylls $a, b$ and total chlorophyll were higher in pods from plants grown on the Bernow soil (Table 9). For plants developed from AM-inoculated seedlings, chlorophyll $a$ and total chlorophyll were higher for plants grown on the Stigler soil. Chlorophyll $b$ was unaffected. For all other combinations, there were no affects on chlorophylls $a, b$ and total chlorophyll.

Carotenoids. Pods from plants developed from conventionally produced seedlings grown on the Bernow soil had higher values than pods from plants grown on the Stigler soil (Table 9). For all other combinations, there were no affects resulting from treatment.

Vitamin C. For conventionally produced seedlings (no inocula), or when plants were inoculated with both bacteria and the AM fungi, total vitamin $\mathrm{C}$ content was higher for pods from plants grown on the Bernow soil (Table 9). When seedlings were inoculated only with the AM fungi, vitamin $\mathrm{C}$ content was higher for pods from plants grown on the Stigler soil.

Fresh marketable pod weight. Only plants developed from seedlings inoculated with bacteria and grown on the Bernow soil had heavier pods than those grown on the Stigler soil (Table 10). For all other combinations, there were no effects resulting from treatment.

Pod chlorophyll, carotenoid and vitamin $C$ contents, and pod fresh weights of conventionally and organically grown plants on the Bernow and Stigler soils, 2008. Total vitamin $\mathrm{C}$ was affected by production 
Table 7. Analysis of variance table for affects of soil management, planting date, and Inoculation treatment, and effect of soil type on marketable and cull yield of plants established on the Bernow soil managed with organic or conventional methods (2008).

\begin{tabular}{|c|c|c|c|}
\hline \multirow{2}{*}{ Source } & & \multicolumn{2}{|c|}{ Yield $\left(\mathrm{Mg} \cdot \mathrm{ha}^{-1}\right)$} \\
\hline & & Marketable & Cull \\
\hline \multicolumn{2}{|c|}{ Production method (P) } & $* *$ & * \\
\hline \multicolumn{2}{|l|}{ Planting date (D) } & ** & NS \\
\hline \multicolumn{2}{|c|}{ Inoculation treatment (I) } & NS & NS \\
\hline \multicolumn{4}{|l|}{ Interaction } \\
\hline \multicolumn{2}{|l|}{$\mathrm{P} \times \mathrm{D}^{\mathrm{z}}$} & $*$ & NS \\
\hline \multicolumn{4}{|l|}{ Interaction } \\
\hline \multicolumn{4}{|c|}{ Planting date $\times$ production method } \\
\hline \multirow[t]{2}{*}{ Spring 2008} & Bernow (conventional) & 3.8 & $\complement^{x}$ \\
\hline & Bernow (organic) & $11.2 * * y$ & - \\
\hline \multirow[t]{2}{*}{ Summer 2008} & Bernow (conventional) & 9.0 & - \\
\hline & Bernow (organic) & $11.0 \mathrm{NS}$ & - \\
\hline
\end{tabular}

${ }^{\mathrm{z}}$ Shown is the only significant interaction.

${ }_{\mathrm{NS}}, * *=$ Nonsignificant or significant at $P \leq 0.01$ for values in planting date $\times$ soil management group, least squares means analysis.

x"_" = Not analyzed by interaction because it was not significant for the response by soil type for the Bernow soil: average cull yield $=0.2 \mathrm{Mg} \cdot \mathrm{ha}^{-1}$ and for the Stigler soil: average cull yield $=1.3 \mathrm{Mg} \cdot \mathrm{ha} \mathrm{H}^{-1}$. NS, $* * *=$ Nonsignificant or significant at $P \leq 0.05$ or $P \leq 0.01$, analysis of variance.

Table 8. Analysis of variance table for effects of soil type and inoculation treatment on chlorophyll, carotenoid, and vitamin $\mathrm{C}$ contents and fresh weights of pods from plants developed from inoculated and uninoculated seedlings established on Bernow or Stigler soils managed with organic methods (2008).

\begin{tabular}{|c|c|c|c|c|c|c|}
\hline \multirow[b]{2}{*}{ Source } & \multicolumn{3}{|c|}{ Chlorophyll } & \multirow[b]{2}{*}{ Carotenoids } & \multirow[b]{2}{*}{ Total vitamin $\mathrm{C}$} & \multirow[b]{2}{*}{ Pod fresh wt } \\
\hline & $\mathrm{a}$ & $\mathrm{b}$ & Total & & & \\
\hline Soil type (S) & NS & $*$ & NS & NS & $* *$ & $*$ \\
\hline Inoculation treatment (I) & NS & NS & NS & $*$ & NS & $*$ \\
\hline $\begin{array}{c}\text { Interaction } \\
\mathrm{S} \times \mathrm{I}\end{array}$ & $* *$ & $* *$ & $* *$ & $* *$ & $* *$ & $* *$ \\
\hline
\end{tabular}

Table 9. Effect of interaction of soil type and inoculation treatment on chlorophyll, carotenoid, vitamin C contents, and fresh pod weight from plants developed from inoculated and uninoculated seedlings established on Bernow or Stigler soils managed with organic methods (2008).

\begin{tabular}{|c|c|c|c|c|c|c|c|}
\hline \multirow{2}{*}{\multicolumn{2}{|c|}{ Inoculation treatment $\times$ soil type }} & \multicolumn{3}{|c|}{ Chlorophyll $\left(\mu \mathrm{g} \cdot \mathrm{g}^{-1}\right)$} & \multirow{2}{*}{$\begin{array}{l}\text { Carotenoids } \\
\quad\left(\mu g \cdot g^{-1}\right)\end{array}$} & \multirow{2}{*}{$\begin{array}{l}\text { Total vitamin C } \\
(\mathrm{mg} / 100 \mathrm{~g})\end{array}$} & \multirow{2}{*}{$\begin{array}{l}\text { Fruit } \\
\text { fresh wt }(\mathrm{g})^{\mathrm{z}}\end{array}$} \\
\hline & & $\mathrm{a}$ & $\mathrm{b}$ & Total & & & \\
\hline \multirow[t]{2}{*}{ None (conventional) } & Bernow & 51.8 & 22.1 & 73.9 & 20.4 & 145.5 & 152.5 \\
\hline & Stigler & $40.3^{* *}$ & $17.2 * *$ & $57.5^{* *}$ & $17.4 * *$ & $109.7 * *$ & $184.8 \mathrm{NS}$ \\
\hline \multirow[t]{2}{*}{ None (organic) } & Bernow & 45.5 & 19.7 & 65.2 & 18.5 & 129.1 & 197.3 \\
\hline & Stigler & $37.2 * *$ & $16.1 * *$ & $53.3^{* *}$ & $16.4 \mathrm{NS}$ & $107.9 \mathrm{NS}$ & $192.9 \mathrm{NS}$ \\
\hline \multirow[t]{2}{*}{ AM (organic) } & Bernow & 43.5 & 19.1 & 62.5 & 18.4 & 125.1 & 207.2 \\
\hline & Stigler & $50.0^{*}$ & $21.2 \mathrm{NS}$ & $71.2 *$ & 20.9 NS & $152.8^{*}$ & $182.0 \mathrm{NS}$ \\
\hline \multirow[t]{2}{*}{ Bacteria (organic) } & Bernow & 45.2 & 19.7 & 64.9 & 18.6 & 129.6 & 210.1 \\
\hline & Stigler & $47.9 \mathrm{NS}$ & $20.1 \mathrm{NS}$ & $68.0 \mathrm{NS}$ & $19.2 \mathrm{NS}$ & $109.1 \mathrm{NS}$ & $145.0 * *$ \\
\hline \multirow[t]{2}{*}{ Both (organic) } & Bernow & 44.2 & 19.3 & 63.5 & 18.6 & 141.5 & 180.7 \\
\hline & Stigler & $48.2 \mathrm{NS}$ & $20.1 \mathrm{NS}$ & $68.3 \mathrm{NS}$ & $20.0 \mathrm{NS}$ & $110.5^{*}$ & $164.9 \mathrm{NS}$ \\
\hline
\end{tabular}

${ }^{\mathrm{z}}$ Fresh fruit weights provided to allow extrapolation of chlorophyll, carotenoid, and vitamin $\mathrm{C}$ contents to whole fruit.

NS, $*, * *=$ Nonsignificant, or significant at $P \leq 0.05, P \leq 0.01$ for values in inoculation treatment $\times$ soil type group, least squares means analysis.

$\mathrm{AM}=$ arbuscular mycorrhizal.

method and inoculation treatment; carotenoid content and fresh pod weight were affected by inoculation treatment (Table 10). Pods from conventionally grown plants had higher vitamin $\mathrm{C}$ levels than those grown organically. Carotenoid level was higher in pods of plants developed from conventionally produced seedlings than from plants developed from organically produced seedlings inoculated with only the AM fungi or with the combination of bacteria and AM fungi. The other treatments produced results intermediate between low and high values. Total seedlings inoculated with the mix of bacteria and AM fungi produced results intermediate between low and high values.

\section{Discussion}

Russo (2006) reported that there was little benefit to development of pepper seedlings as a result of inoculation with the same mixes of microorganisms used in this project. As an extension of that work, it was determined that inoculation treatment had little effect on pod yield. In one instance, use of the bacteria, or the AM fungi as inoculants, was detrimental to yield. However, this occurred at one planting date and on the Stigler soil so that an all-encompassing conclusion cannot be drawn. Use of AM fungi has been reported to be detrimental to bell pepper development (Makus, 2005; Nemec et al., 1996) as seems to be the case here with different soils, locations, and planting dates.

Changes in yield seemed to be the result of environmental conditions during the growing season. Environmental conditions may have affected microorganism activity after transfer of inoculated plants to the field. Even in the same year, yield differences were not consistent for soil type suggesting that environmental conditions were the controlling factors. When yield was reduced using organic management, it was associated with soil type or planting time.

Mineral content of pods was not much affected by inoculation treatment or whether plants were grown conventionally or organically. Where pod fresh weight was affected, inoculation with the bacteria or the AM fungi provided some benefit over pod fresh weights from plants developed from conventionally produced seedlings. However, plants developed from organically produced seedlings, that were not inoculated, had pods of equal weight as those on plants developed from organically produced, inoculated seedlings. This suggests that organic production from seedlings to harvest may be beneficial for production of heavier pods, but inoculation does not appear to be necessary.

Inoculation treatment affected content of chlorophyll, total carotenoids, and vitamin C, and values were usually lower from pods from plants produced on the Stigler soil. The soils had different production histories and compositions. Soil ecology affects plant development, which is, in part, the result of the presence of specific microorganisms in soils (Lavelle and Spain, 2002). How populations of microorganisms in the soil types change over time, and the influence different cropping patterns exert, needs additional study.

Planting was initiated after the Stigler soil was converted from perennial pasture that had not received synthetic chemical pest control or synthetic fertilizer for at least 10 years. Russo and Roberts (1991) found that when perennial pasture was converted to conventional vegetable production, there was a lag in realizing desired yield levels. When perennial pasture was transitioned to organic production, a similar lag time was 
Table 10. Analysis of variance table for affects of production method and inoculation treatment on chlorophyll, carotenoid, and vitamin $\mathrm{C}$ contents of pods of plants developed from inoculated and uninoculated seedlings grown conventionally or organically on a Bernow soil (2008).

\begin{tabular}{|c|c|c|c|c|c|c|}
\hline \multirow[b]{2}{*}{ Source } & \multicolumn{3}{|c|}{ Chlorophyll } & \multirow[b]{2}{*}{ Carotenoids } & \multirow[b]{2}{*}{ Total vitamin $\mathrm{C}$} & \multirow[b]{2}{*}{ Pod fresh wt } \\
\hline & $\mathrm{a}$ & $\mathrm{b}$ & Total & & & \\
\hline Production method (P) & NS & NS & NS & NS & * & NS \\
\hline Inoculation treatment (I) & NS & NS & NS & $*$ & $*$ & $*$ \\
\hline \multicolumn{7}{|l|}{ Interaction } \\
\hline $\mathrm{P} \times \mathrm{I}$ & NS & NS & NS & NS & NS & NS \\
\hline \multicolumn{7}{|l|}{ Production method } \\
\hline Conventional & & & & $-^{\mathrm{z}}$ & $148.2 \mathrm{a}^{\mathrm{y}}$ & - \\
\hline Organic & & & & - & $134.4 \mathrm{~b}$ & - \\
\hline \multicolumn{7}{|l|}{ Inoculation treatment } \\
\hline Conventional & & & & $20.5 \mathrm{a}$ & $157.2 \mathrm{a}$ & $162.2 \mathrm{~b}$ \\
\hline None (organic) & & & & $19.1 \mathrm{ab}$ & $142.8 \mathrm{ab}$ & $201.9 \mathrm{a}$ \\
\hline Bacteria (organic) & & & & $19.6 \mathrm{ab}$ & $135.8 \mathrm{ab}$ & $195.2 \mathrm{a}$ \\
\hline AM (organic) & & & & $18.7 \mathrm{~b}$ & $130.0 \mathrm{~b}$ & $194.6 \mathrm{a}$ \\
\hline Both (organic) & & & & $18.7 \mathrm{~b}$ & $140.4 \mathrm{ab}$ & $186.5 \mathrm{ab}$ \\
\hline
\end{tabular}

"_-" = These data are not significant and provided as averages in the appropriate section.

${ }^{y}$ Values in a column followed by the same letter are not significantly different, $P \leq 0.05$, Ryan-EinotGabriel-Welsch multiple range test.

NS, $*=$ Nonsignificant or significant at $P \leq 0.05$, analysis of variance.

$\mathrm{AM}=$ arbuscular mycorrhizal.

noted in yield levels of vegetables (Russo and Taylor, 2006). The transition time from perennial pasture to vegetable production may account for the apparently reduced yields found from plants on the Stigler soil through to 2008 .

The microorganisms used in this project did not appear to provide a specific benefit to bell pepper yield or content of most nutrients in pods. The limitation for use of conventionally produced seedlings in an organic system is not on yield but on the effect on the organic certification. If organically produced seedlings are used in a conventional production system, it appears that yield targets can be achieved. The influence of the use of organically produced seedlings on the overall conventional production system is relatively small, but there would be a reduction in the amount of synthetic fertilizer and conventional potting mix used. The potting media used in this project have qualities that make them acceptable for vegetable transplant production. Other potting materials exist to which results obtained here, and previously (Russo, 2005), could be compared, especially regarding organic production.

Microorganisms in soil affect soil tilth, plant health, nutrient uptake, rhizosphere populations, and other factors of the soilplant interaction (Lavelle and Spain, 2002; Suresh and Bagyaraj, 2002). It appears that amending potting mix with the microorganisms tested did not provide enough benefit to yield to recommend use for bell pepper production. There are other microorganism formulations commercially available that should be screened for effects on plant development and yield, especially for use in organic production.

\section{Literature Cited}

Andrews, M., E.K. James, S.P. Cummings, A.A. Zavalin, L.V. Vinogradova, and B.A. McKenzie.
2003. Use of nitrogen fixing bacteria inoculants as a substitute for nitrogen fertilizer for dryland graminaceous crops: Progress made, mechanisms of action and future potential. Symbiosis 35:209-229.

Cantliffe, D.J. 1993. Pre- and postharvest practices for improved vegetable transplant quality. HortTechnology 3:415-418.

Damato, G. and L. Trotta. 2000. Cell shape, transplant age, cultivars and yield in broccoli. Acta Hort. 533:153-160.

de Grazia, J., P. Tittonell, and A. Chiesa. 2002. Pepper (Capsicum annuum L.) transplant growth as affected by growing medium compression and cell size. Agronomie 22:503-509.

Douds, D.D., Jr. and C. Reider. 2003. Inoculation with mycorrhizal fungi increases the yield of green peppers in a high $\mathrm{P}$ soil. Biol. Agric. Hort. 21:91-102.

Dufault, R.J. 1998. Vegetable transplant nutrition. HortTechnology 8:515-523.

Emitiazi, G., Z. Etemadifar, and M. Tavassoli. 2003. A novel nitrogen-fixing cellulytic bacterium associated with root of corn is a candidate for production of single cell protein. Biomass Bioenergy 25:423-426.

Glick, B.R. 2004. Changes in plant growth and development by rhizosphere bacteria that modify plant ethylene levels. Acta Hort. 631:265-273.

Hartz, T.K., C. Giannini, E.M. Miyao, and J.G. Valencia. 2002. Divergent transplant production practices produce compatible growth, yield, and quality of processing tomatoes. HortScience 37:296-299.

Hodges, D.M., W.V. Wismer, and C.F. Forney. 2001. Antioxidant responses in harvested leaves of two cultivars of spinach differing in senescence rates. J. Amer. Soc. Hort. Sci. 126: 611-617.

Jones, J.B., Jr. and V.W. Case. 1990. Sampling, handling, and analyzing plant tissue samples, p. 389-428. In: Westerman, R.L. (ed.). Soil testing and plant analysis. 3rd Ed. Soil Science Society of America, Madison, WI.

Kokalis-Burelle, N., J.W. Klopper, R. RodriguezKábana, C.S. Vavrina, E.N. Rosskopf, and D.S. Kenney. 1999. Evaluation of amended transplant mixes for fruit and vegetable production. 3 Feb. 2010. <http://www.epa.gov/ozone/ strathome.html>.
Kokalis-Burelle, N., C.S. Vavrina, M.S. Reddy, and J.W. Klopper. 2003. Amendment of muskmelon and watermelon transplant media with plant growth-promoting rhizobacteria: Effects on seedling quality, disease, and nematode resistance. HortTechnology 13:476482.

Koller, M., T. Alfoldi, M. Siegrist, and F. Weibel. 2004. A comparison of plant and animal based fertiliser for the production of organic vegetable transplants. Acta Hort. 631:209-215.

Lavelle, P. and A. Spain. 2002. Soil ecology. Springer-Verlag, Berlin, Germany.

Lichtenthaler, H.K. and C. Buschmann. 2001. Extractions of photosynthetic tissues: Chlorophylls and carotenoids, p. F4.2.1.-F4.2.6. In: Wrolstad R.E., T.E. Acree H. An, E.A. Decker, M.H. Penner, D.A. Reid, S.J. Schwartz, C.F. Shoemaker, and P. Sporns. Current protocols in food analytical chemistry. J.W. Wiley \& Sons, New York, NY.

Linderman, R.G. and E.A. Davis. 2001. Vesiculararbuscular mycorrhiza and plant growth responses to soil amendment with composted grape pomace or its water extract. HortTechnology 11:446-450.

Lucy, M., E. Reed, and B.R. Glick. 2004. Applications of free living plant growth-promoting rhizobacteria. Antonie Van Leeuwenhoek 86: $1-25$.

Makus, D.J. 2005. Effect of mulch, mycorrhizal inoculation, and surround on late fall pepper production. HortScience 40:999 (abstr.).

Martin, C.A. and J.C. Stutz. 2004. Interactive effects of temperature and arbuscular mycorrhizal fungi on growth, $\mathrm{P}$ uptake and root respiration of Capsicum annuum L. Mycorrhiza 14:241-244.

Maynard, D.N. 2000. Triploid watermelon transplant production. Acta Hort. 533:109-112.

Motes, J.E. and W. Roberts. 1994. Fertilizing commercial vegetables. OSU Extension Facts F-6000. Oklahoma State University, Stillwater, OK.

Nemec, S., L.E. Datnoff, and J. Standberg. 1996. Efficacy of biocontrol agents in planting mixes to colonize plant roots and control root diseases of vegetables and citrus. Crop Prot. 15:735-742.

Nicola, S., J. Hoeberechts, and E. Fontana. 2004 Studies on irrigation systems to grow lettuce (Lactuca sativa L.) transplants. Acta Hort. 631:141-148.

Rippy, J.F.M., M.M. Peet, F.J. Louws, P.V. Nelson, D.B. Orr, and K.A. Sorensen. 2004. Plant development and harvest yield of greenhouse tomatoes in six organic growing systems. HortScience 39:223-229.

Russo, V.M. 2004. Greenhouse-grown transplants as an alternative to bare-root transplants for onion. HortScience 39:1267-1271.

Russo, V.M. 2005. Organic vegetable transplant production. HortScience 40:623-628.

Russo, V.M. 2006. Biological amendment, fertilizer rate, and irrigation frequency for organic bell pepper transplant production. HortScience 41:1402-1407.

Russo, V.M. and S.V. Karmakar. 1998. Water extraction of plant tissues for analysis by ion chromatography. Commun. Soil Sci. Plant Anal. 29:245-253.

Russo, V.M. and B.W. Roberts. 1991. Variable yield of bell pepper established on converted perennial pasture fertilized according to recommendations. HortTechnology 1:39-41.

Russo, V.M. and M. Taylor. 2006. Soil amendments in transition to organic vegetable production with comparison to conventional methods: Yields and economics. HortScience 41:1576-1583. 
Schulze, J. and G. Pöschel. 2004. Bacterial inoculation of maize affects carbon allocation to roots and carbon turnover in the rhizosphere. Plant Soil 267:235-241.

Shimshick, E.J. and R.R. Herbert. 1979. Bincing characteristics of $\mathrm{N}_{2}$-fixing bacteria to cereal roots. Appl. Environ. Microbiol. 38:447-453.

Shingleton, L.C. and A. Watterson, Jr. 1979. Soil survey of Atoka County Oklahoma. US Department of Agriculture, Soil Conservation Service, Washington, DC.

Singh, R. and A. Adholeya. 2002. Plant and fungal responses to colonization, p. 213-230. In: Sharma, A.K. and B.N. Johri (eds.). Arbuscular mycorrhizae: Interactions in plants, rhizosphere, and soils. Science Publishers, Enfield, NH.

Sterrett, S.B., C.W. Reynolds, F.D. Schales, R.L Chaney, and L.W. Douglass. 1983. Transplant quality, yield, and heavy-metal accumulation of tomato, muskmelon, and cabbage grown in media containing sewage sludge compost. J Amer. Soc. Hort. Sci. 108:36-41.

Suresh, C.K. and D.J. Bagyaraj. 2002. Mycorrhizamicrobe interactions: Effect on rhizosphere, p. 7-28. In: Sharma, A.K. and B.N. Johri (eds.). Arbuscular mycorrhizae. Interactions in plants, rhizosphere and soils. Science Publishers, Enfield, NH.

United States Department of Agriculture, Agricultural Marketing Service. 1994. United States standards for grades of Sweet Peppers 25 FR 2879 [amended 3 Jan. 1989 (53 FR 48630)]. 3 Feb. 2010. <http://www.ams.usda. gov/standards/PEPERSWT1.pdf $>$.

United States Department of Agriculture, Agricultural Marketing Service. 2000. National Organic Program; Final rule. 7 CFR Part 205. Fed. Regist. 21 Dec. 2000.
Vavrina, C.S. 1998. Transplant age in vegetable crops. HortTechnology 8:550-555.

Vavrina, C.S. and P.D. Roberts. 2004. Use of commercial systemic resistance (SAR) inducers in the stand establishment of tomato; impact of plant growth, disease and nematode suppression. Acta Hort. 631:231-238.

Waterer, D.R. and R.R. Coltman. 1989. Response of mycorrhizal bell peppers to inoculation timing, phosphorus, and water stress. HortScience 24:688-690.

Zahir, Z.A., M. Arshad, and W.T. Frankenberger. 2004. Plant growth promoting rhizobacteria: Applications and perspectives in agriculture. Adv. Agron. 81:97-168.

Zehnder, G.W., J.F. Murphy, E.J. Sikora, and W. Klopper. 2001. Application of rhizobacteria for induced resistance. Eur. J. Plant Pathol. 107: $39-50$. 